\title{
PENGARUH INTENSITAS PERAN AKUNTANSI MANAJEMEN DAN KETIDAKPASTIAN LINGKUNGAN TERHADAP KUALITAS PELAYANAN SISTEM INFORMASI PERUSAHAAN
}

\author{
Oleh: \\ Drajat Armono "
}

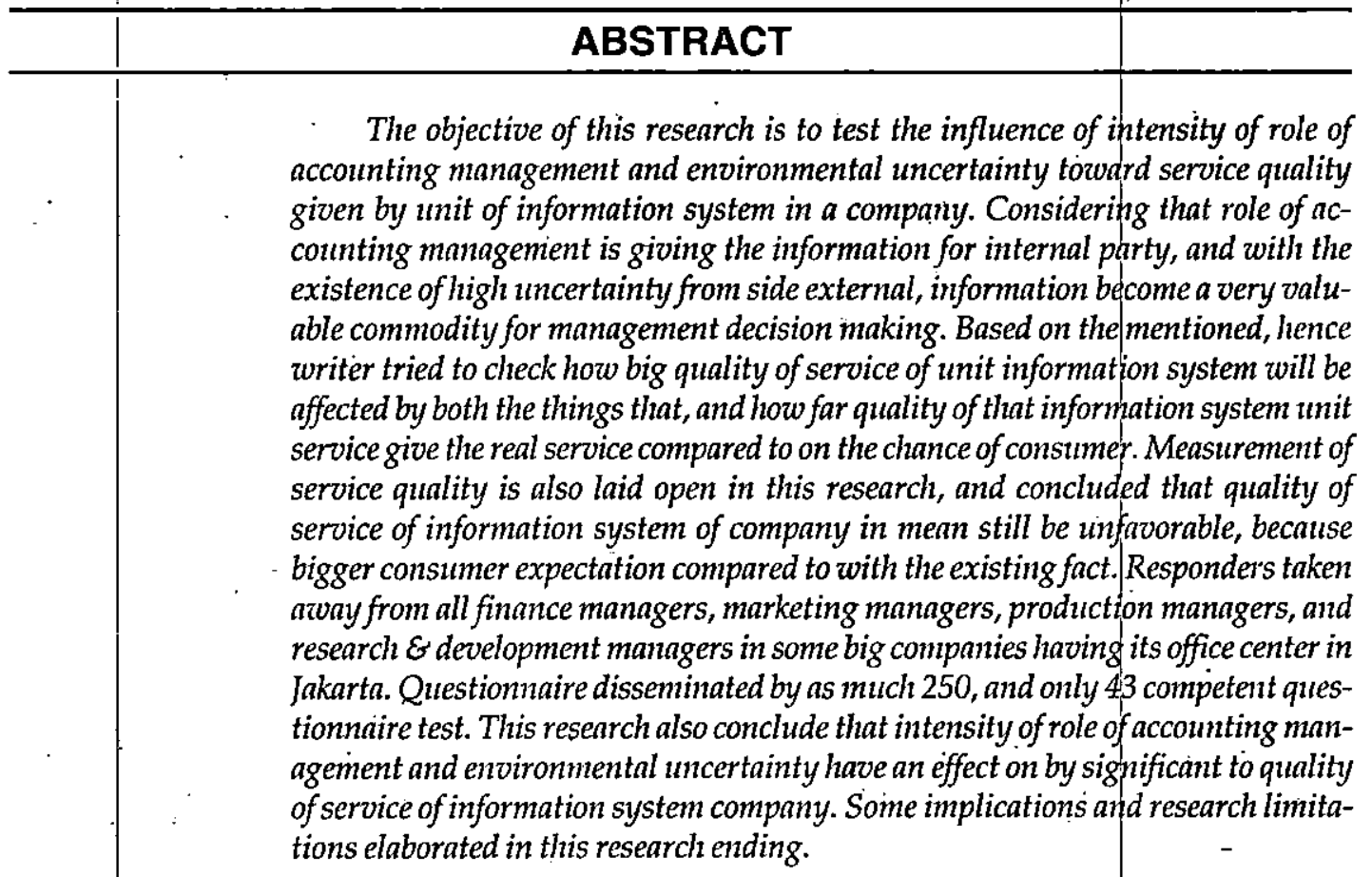

Key words: service quality, intensity of role of management accounting, environmental uncertainty

A. Piendahuluan

Informasi yang diberikan oleh unit sistem informasi menjadi sesuatu yang penting dalam mendukung keputusan-keputusan manajemen. Hal tersebut menjadikan peranan unit sistem informasi meningkat pada akhir-akhir ini. Kebutuhan informasi dalam suatu perusahaan akan tergantung pada berbagai

*) Drajat Armono adalạh Dosen Fakultas Ekonomi Universitas Islam Indonesia 
faktor, antara lain adalah intensitas peran akuntansi manajemen dan ketidakpastian lingkungan. Dengan demikian ada dugaan bahwa intensitas peran akuntansi manajemen dan ketidakpastian lingkungan akan berpengaruh pada informasi yang akan diberikan oleh unit sistem informasi dalam suatu perusahaan. Pengukuran keefektifan unit sistem informasi dapat dilihat pada perspektif kualitas sistemnya dan juga kualitas informasinya (Pitt, dkk, 1995). Keefektifan sistem informasi ini juga dapat dilihat dari kualitas pelayanan yang diberikan oleh unit sistem informasi. Kualitas pelayanan ini digunakan untuk mengukur kepuasan pelanggan terhadap layanan perusahaan. Penelitian mengenai keefektifan sistem informasi sudah banyak dilakukan, antara lain oleh Pitt, dkk, (1995), mengenai keefektifan sistem informasi dilihat dari dimensi kualitas pelayanan. Penelitian lain mengenai ketidakpastian lingkungan, menyatakan bahwa jika ketidakpastian tinggi, maka pengambilan keputusan memerlukan informasi yang lebih banyak, jika dibandingkan dengan ketidakpastian yang rendah (Galbraith, 1973 dalam Supardiyono, 1999). Temuantemuan penelitian kadang-kadang juga mengeciikan hati para akuntan. Rasyid (1998) menemukan bahwa, tidak ada peran akuntansi manajemen di perusahaan. Hal tersebut merupakan keanehan bagi akuntan, karena perusahaan tempat Rasyid (1998) melakukan penelitian adalah sebuah perusahaan terbuka yang menguasai pasaran air minum dalam kemasan di Indonesia. Penelitian Sjoblom (1998) menemukan bahwa, informasi kos kualitas bukan merupakan indikator penting bagi manajemen kualitas. Ukuran-ukuran statistik seperti tingkat kegagalan internal/eksternal, kepuasan konsumen dan lain-lain lebih dipertimbangkan untuk pengambilan keputusan-keputusan manajemen kualitas. Penelitian Kottler dan Heskett (1992), menunjukkan bahwa kinerja perusahaan dilihat dari laporan keuangan yang didasarkan pada standar akuntansi keuangan. Dalam pandangan akuntan, mana mungkin perusahaan dapat berjalan dengan baik tanpa mendapat dukungan dan memanfaatkan informasi akuntansi manajemen. Oleh karena akuntansi merupakan cabang ilmu terapan, Sudibyo (1986) mengajukan pandangan akuntansi sebagai suatu teknologi. Sebagai suatu teknologi, akuntansi akan diadopsi oleh pemakai sesuai dengan kebutuhannya. Pengadopsian informasi akuntansi keuangan dapat terjadi karena tekanan pihak luar, sedangkan pengadopsian informasi akuntansi manajemen lebih ditentukan oleh kebutuhan pihak manajemen. Hal-hal tersebut di atas mendorong penulis untuk meneliti permasalahan tersebut. Bagi perusahaan yang menghadapi ketidakpastian lingkungan yang tinggi, akan lebih intensif melaksanakan fungsi pengendalian. Pengendalian dilakukan manajemen untuk mengurangi resiko. Dasar pemikirannya adalah hasil yang baik merupakan konsekuensi logis dari adanya pengendalian yang baik. Jika ketidakpastian lingkungan tinggi, maka pengambilan keputusan memerlukan informasi yang lebih banyak, jika dibanding dengan ketidakpastian yang rendah (Galbraith, 1973 dalam Supardiyono, 1999). Sebaliknya, bila kondisi ketidakpastian rendah, maka interpretasi lingkungan menjadi lebih mudah, dan manajer secara relatif dapat membuat prediksi yang akurat. Di samping itu, untuk menghadapi ketidakpastian lingkungan yang dihadapi lingkungan organisasi, suatu unit sistem informasi dituntut untuk lebih efektif dilihat dari dimensi kualitas pelayanan, sehingga nantinya diharapkan dapat memberikan pelayanan yang terbaik kepada 
Drajat Armono: Pengaruh Intensitas Peran Akuntansi Manajemen dan Ketidakpastian...

para penggunanya. Penelitian mengenai intensitas peran akuntansi manajemen pernah dilakukan Eka (2000), yang menghubungkan intensitas peran akuntansi manajemen dengan budaya organisasi dan mendapatkan hasil yang signifikan. Tetapi peneliti sebelumnya belum menghubungkan intensitas peran akuntansi manajemen dengan sesuatu yang berhubungan dengan informasi. Penulis berpendapat, dengan hasil yang didapat dari penelitian tersebut, maka kualitas pelayanan sebuah unit organisasi tentunya dipengaruhi juga oleh budayanya, maka peneliti menghubungkan intensitas peran akuntansi manajemen dengan kualitas pelayanan. Keterkaitan lain dari intensitas peran akuntansi manajemen dengan kualitas pelayanan sistem informasi dipandang dari segi informasi sebagai suatu yang sangat diperlukan dalam sebuah unit organisasi, karena pengadopsian informasi akuntansi manajemen lebih ditentukań oleh kebutuhan pihak manajemen. Penelitian mengenai ketidakpastian lingkungan yang dihubungkan dengan kualitas pelayanan sistem informasi yang dilakukan oleh Wahyu (2001), mendapatkan hasil yang tidak signifikan pada alpha $5 \%$. Hal tersebut juga menggugah motivasi penulis untuk meneliti hal tersebut, karena secara logika dengan adanya ketidakpastian lingkungan yang tinggi, maka informasi akan menjadi komoditas yang sangat berharga dan tentunya akan mempengaruhi kualitas pelayanan yang diberikan oleh unit sistem informasi.Dari uraian latar belakang di atas, maka permasalahan dapat dirumuskan dalam bentuk pertanyaan sebagai berikut:

1. Apakah sistem informasi perusahaan yang menggunakan unit sistem informasi sudah efektif dipandang dari dimensi kualitas p'elayanan?

2. Apakah keintensitasan peran akuntansi manajemen mempengaruhi kualitas pelayanan yang diberikan oleh unit sistem informasi?

3. Apakah ketidakpastian lingkungan akan mempengaruhi kualitas pelayanan yang diberikan oleh unit sistem informasi?

\section{B. TELAAH LITERATUR DAN HIPOTESIS}

\section{Kualitas Pelayanan}

Fungsi sistem informasi termasuk ke dalam komponen jasa yang penting. Meskipun demikian, cara pengukuran keefektifan fungsi sistem informasi yang umumnya digunakan lebih berfokus pada produk dibanding jasanya. Servqual adalah sebuah instrumen yang ditawarkan sebagai alat pengukur kualitas jasa sistem informasi dan dikembangkan oleh bagian pemasaran. Menurut Pitt, dkk (1995), kualitas pelayanan mempunyai lima dimensi jasa atau servis, yaitu tangible (tingkat kenyataan), reliability (ketahanan uji), responsiveness (respon), assurance (jaminan), dan empathy (empati). Tangible meliputi fasilitas fisik, peralatan, dan personal yàng ada. Reliability adalah kemampuan untuk membentuk pelayanan yang dijanjikan dengan akurat dan dapat dipercaya. Responsiveness adalah keinginan untuk membantu para pelanggan dan memberikan pelayanan sebaik mungkin. Assurance adalah pengetahuan dan kesopansantunan para pegawai perusahaan serta kemampuan mereka menumbuhkan rasa percaya para pelanggan kepada perusahaan. Empathy 
adalah perhatian yang tulus yang dapat diberikan kepada pelanggan. Variabel kualitas pelayanan ini diukur dengan menggunakan instrumen servqual (service quality) yang telah ditawarkan oleh Pitt, dkk, 1995. Instrumen itu terdiri atas dua bagian, yaitu harapan (expected) dan kenyataan (perceived) yang masing-masing memiliki indikator tangible, reliability, responsiveness, assurance, dan empathy. Dalam instrumen servqual (service quality), pengujian ratarata harapan (expectation) dan kenyataan (perceived) pengguna informasi diselisihkan (Parasuraman, dkk, 1988; Boulding dan Stealing, 1993; Pitt, dkk. 1995) untuk mendapatkan kualitas pelayanan. Suhaily (1999) menyatakan bahwa pengukuran kualitas pelayanan dalam industri pelayanan khususnya industri hotel adalah penting, tetapi pada kenyataannya sulit diukur, karena tidak ada model tunggal/teknik yang dapat digunakan untuk mengukur kualitas pelayanan secara sempurna. Menurut Delone Mc Lean, 1992, dalam Wahyu 2001, keefektifan sistem informasi merupakan konsepsi yang multidimensional dan tidak ada ukuran tunggal dari kesuksesan sistem informasi, sehingga berkonsekuensi dibutuhkannya pengukur yang banyak. Delone Mc Lean mengidentifikasikan enam kategori pengukur keefektifan sistem informasi yaitu kualitas sistem, kualitas informasi, penggunaan informasi, kepuasan pengguna, pengaruh individual dan pengaruh organisasi. Berikut adalah hubungan kategori tersebut:

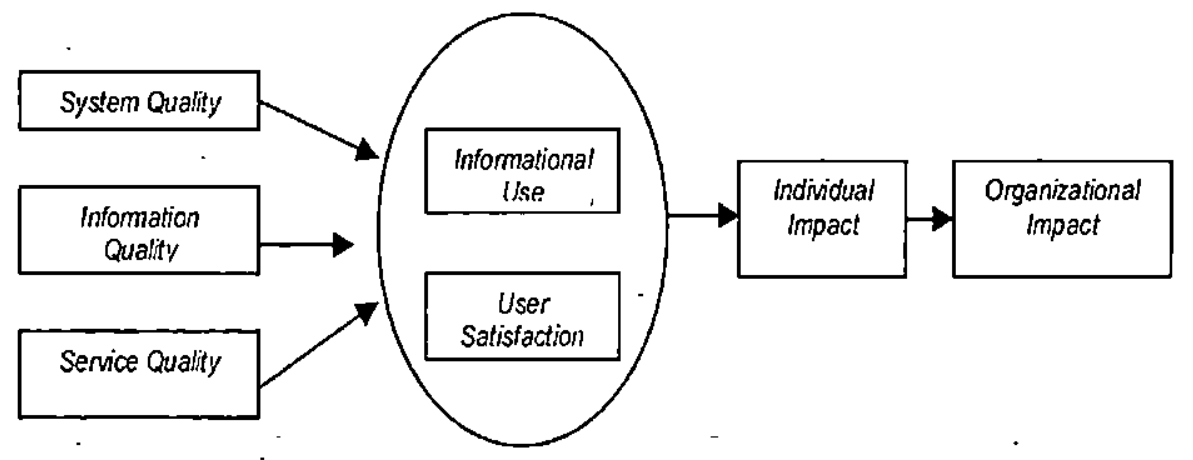

Sumber: Pitt, 1995 (Argumented IS Succes Model. Ackpted from Delone and Nic Lean, 1992).

\section{Pelayanan Unit Sistem Informasi}

Departemen sistem informasi memiliki peran yang besar karena merupakan pembangun dan pelaksana sistem informasi. Pengemalan komputer pribadi atau personal computer/PC, menyebabkan lebih banyak pengguna teknologi informasi yang tertarik dengan departemen sistem informasi. Para pengguna berharap agar departemen sistem informasi dapat membantu tugastugas mereka yang cukup banyak seperti pemilihan perangkat lunak (software) dan perangkat keras (hardware), instalasi; pemecahan masalah, hubungan dengan pengembangan sistem dan lainnya. Alasan utama mengapa departemen sistem informasi mengukur tingkat kepuasan penggunanya adalah agar dapat meningkatkan kualitas jasa yang mereka sediakan dan dampaknya terhadap organisasi (Conrath dan Mignen, 1990 dalam Pitt, dkk,1995). Memberikan 
Drajat Armono: Pengaruh Intensitas Peran Akuntansi Manajemen dan Ketidakpastian...

pelayanan yang baik merupakan sesuatu hal yang tidak mudah untuk dicapai. Dalam organisasi banyak orang yang mempunyai kebutuhan dan kepentingan yang berbeda-beda. Unit sistem informasi harus dapat memenuhi kebutuhankebutuhan pengguna sistem informasi. Pengguna sistem informasi mengharapkan bahwa informasi yang dihasilkan diharapkan dapat memer uhi karakteristik sistem informasi yaitu: timelines, accuracy, relevance, corroboration, redudancy, dan data presentation. Menurut Wilkinson, 2000 , pelayanan system informasi yang baik haruslah dapat mencapai sasaran seperti relevance, consistence, adequate discriminant, appropriate scope, timelines, dan reliability. Pelayanan yang diberikan oleh unit sistem informasi ini diuji dengan menggunakan instrumen servqual (service quality). Dalam pengujian ini nilai harapan dan kenyataan pengguna sistem informasi diselisihkan (Parasuraman, $d k k$, 1988; Boulding dan Stealing, 1993:; Pitt $d k k$. 1995) untuk mendapatkan kualitas pelayanan. Bila pelayanan yang dirasakan (persepsian/kenyataan) lebih besar atau sama dengan yang diharapkan (ekspektasian), maka unit sistem informasi mempunyai kualitas yang baik dalam memberikan pelayanan kepada unit-unit yang lain di dalam perusahaan. Pengujian dilakukan supaya manajemen mengetahui pelayanan yangdiberikan oleh unit sistem informasi kepada unit-unit yang lain apakah sudah sesuai dengan yang diharapkan ataukah belum. Hal tersebut perlu dilakukan mengingat pembangunan sistem informasi yang ada di dalam perusahaan memakan biaya yang tidak sedikit. Sehingga hipotesis pertama dapat dirumuskan sebagai berikut:

H1: Ada perbedaan antara kualitas pelayanan harapan (ekspektasian) dengan kualitas pelayanan kenyataan (persepsian) yang diberikan oleh unit sistem informasi kepada manajer-manajer di luar unit sistem informasi.

\section{Intensitas Peran Akuntansi Manajemen dan Kualitas Pelayanan}

Pengertian peran akuntansi manajemen disini adalah manfaat karakteristik informasi akuntansi manajemen yảng dirasakan oleh para manajer dalam pembuatan keputusan (Chenhal dan Morris, 1986). Penelitian ini hanya menekankan pada manajemen kos yang mencakup sistem akuntansi manajemen, pengambilan keputusan, perencanaan dan pengendalian. Penelitian ini mengembangkan instrumen yang dikembangkan oleh (Harun, 1993; Hendarjatno, 1995; Yadiati, 1993; dalam Eka, 2000). Penelitian ini menekankan pada manajemen kos yang mencakup sistem akuntansi manajemen, pengambilan keputusan, perencanaan dan pengendalian. Harun, 1993; Hendarjanto, 1995; dan Yadiati, 1993 dalam Eka, 2000 meneliti faktor-faktor yang mempengaruhi penerapan teknik akuntansi manajemen. Akuntansi Manajemen menghasilkari informasi yang berguna untuk membantu para pekerja, manajer, dan eksekutif untuk membuat keputusän yang lebih baik (Atkinson, 1995). Pada kenyataannya informasi akuntansi manajemen didominasi oleh informasi finansial. Salah satu perbedaan menonjol antara informasi akuntansi keuangan dengan informasi akuntansi manajemen adalah polanya. Informasi akuntansi keuangan mengikuti pola yang telah ditentukan dalam standar akuntansi, sedangkan informasi akuntansi manajemen tidak 
mempunyai pola tertentu, sehingga dimungkinkan memiliki banyak variasi dan teknik. Penelitian ini hanya menekankan pada manajemen kos yang mencakup sistem akuntansi manajemen, pengambilan keputusan, perencanaan dan pengendalian. Perkembangan teknik-teknik akuntansi manajemen kontemporer lebih berorientasi pada proses. Tetapi, orientasi tersebut memungkinkan perusahaan untuk selalu siap dengan perubahan. Penelitian ini mengembangkan instrumen tersebut untuk mengukur intensitas peran akuntansi manajemen. Temuan-temuan penelitian kadang-kadang mengecilkan hati para akuntan. Rasyid (1998) menemukan bahwa, tidak ada peran akuntansi manajemen di perusahaan. Hal tersebut merupakan keanehan bagi akuntan, karena perusahaan tempat Rasyid (1998) melakukan penelitian adalah sebuah perusahaan terbuka yang menguasai pasaran air minum dalam kemasan di indonesia. Penelitian Sjoblom (1998) menemukan bahwa, informasi kos kualitas bukan merupakan indikator penting bagi manajemen kualitas. Ukuran-ukuran statistik seperti tingkat kegagalan internal/eksternal, kepuasan konsumen dan lain-lain lebih dipertimbangkan untuk pengambilan keputusan-keputusan manajemen kualitas. Penelitian Kottler dan Heskett (1992), menunjukkan bahwa kinerja perusahaan. dilihat dari laporan keuangan yang didasarkan pada standar akuntansi keuangan. Oleh karena akuntansi merupakan cabang ilmu terapan, Sudibyo (1986) mengajukan pandangan akuntansi sebagai suatu teknologi. Sebagai suatu teknologi, akuntansi akan diadopsi oleh pemakai sesuai dengan kebutuhannya. Pengadopsian informasi akuntansi keuangandapat terjadi karena tekanan pihak luar, sedangkan pengadopsian informasi akuntansi manajemen lebih ditentukan oleh kebutuhan pihak manajemen. Dalam pandangan akuntan, mana mungkin perusahaan dapat berjalan dengan baik tanpa mendapat dukungan dan memanfaatkan informasi akuntansi manajemen. Apresiasi terhadap akuntansi, terutama dalam hal ini peran akuntansi manajemen diterjemahkan sebagai optimalisasi fungsi informasi akuntansi yang dihasilkan. Hal-hal tersebut di atas mendorong peneliti memunculkan hipotesis yang kedua,

\section{H2: Intensitas peran akuntansimanajemen berpengaruh secara positif terhadap kualitas pelayanan yang diberikan oleh unit sistem informasi.}

\section{Ketidakpastian Lingkungan dan Kualitas Pelayanan}

Ketidakpastian lingkungan adalah kondisi lingkungan ekstemal yang dapat mempengaruhi operasionalisasi sebuah organisasi atau perusahaan (Outley, 1980 dalam Wahyu Sapto Rini, 2001). Ketidakpastian ini merupakan teori yang dipelopori oleh Burn dan Staker, 1961. Burn dan Staker mencoba mengidentifikasikan tipe struktur dan praktek manajemen yang tepat untuk berbagai kondisi lingkungan yang berbeda. Secara definisi menurut Miliken (1987), ketidakpastian lingkungan merupakan rasa ketidakmampuan individu dalam memprediksi sesuatu secara tepat dan persepsi ketidakpastian lingkungan didefinisikan sebagai persepsi individual atas ketidakpastian yang berasal dari lingkungan organisasi. Variabel ketidakpastian merupakan faktor yang sangat yang penting karena kondisi tersebut akan membuat kegiatan perencanaan dan kontrol menjadi lebih sulit, (Chenhall dan Morris, 1986). Dalam kondisi dengan ketidakpastian yang tinggi, informasi merupakan komoditi yang sangat 
Drajat Arrono: Pengaruh Intensitas Peran Akuntansi Manajemen dan Ketidakpastian...

ma

berguna dalam pengambilan keputusan, sehingga variabel ini tidak cukup dijadikan sebagai variabel pemoderasi saja. Variabel ketidakpastian diukur dengan menggunakan instrumen yang ditawarkan Gordon dan Narayan, 1994 (dalam Supardiyono, 1999). Bagi perusahaan yang menghadapi ketidakpastian lingkungan yang tinggi, akan lebih intensif melaksanakan fungsi pengendalian. Pengendalian dilakukan manajemen untuk mengurangi resiko. Dasar pemikirannya adalah hasil yang baik merupakan konsekuensi logis dari adanya pengendalian yang baik. Jika ketidakpastian lingkungan tinggi, maka pengambilan keputusan memerlukan informasi yang lebih banyak, jika dibanding dengan ketidakpastian yang rendah (Galbraith, 1973 dalam Supardiyono, 1999). Sebaliknya, bila kondisi ketidakpastian rendah, maka interpretasi lingkungan menjadi lebih mudah, dan manajer secara relatif dapat membuat prediksi yang akurat. Berdasar hal tersebut maka penulis memunculkan hipotesis ketiga,

H3: Ketidakpastian lingkungan berpengaruh secara positif terhadap kualitas pelayanan yang diberikan oleh unit sistem informasi.

\section{Model Penelitian}

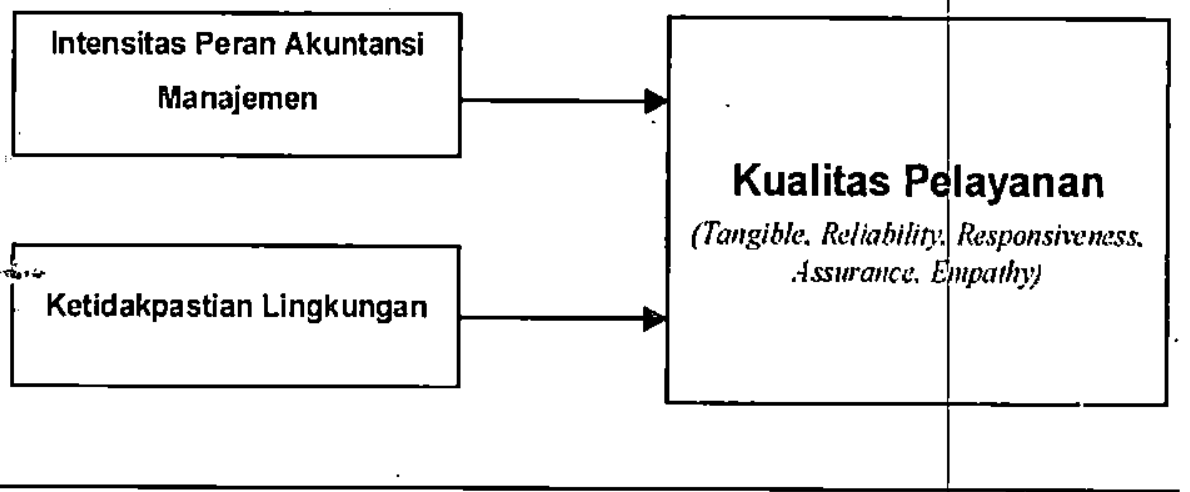

\section{METODE PENELITIAN}

\section{Pemilihan Sampel dan Pengumpulan Data}

Penèlitian ini menggunakan metode survei. Sampel dalam penelitian ini adalah perusahaan yang bergerak di bidang jasa dan manufaktur yang sedang atau telah mengembangkan sistem informasi berbasis komputer. Karena tidak tersedianya daftar perusahaan yang sedang atau telah mengembangkan sistem informasi yang berbasis komputer, maka populasi yang ditentukan adalah perusahaan besar yang mempunyai kantor pusat di Jakarta, tanpa membedakan apakah perusahaan tersebut merupakan perusahaan milik negara atau swasta penuh. Hal tersebut dilakukan dengan pertimbangan bahwa perusahaanperusahaan besar akan memiliki kegiatan operasional yang kompleks. Kompleksitas tersebut tentunya akan mendorong perusahaan untukmengadopsi teknologi, termasuk diantaranya teknologi informasi. Informasi identitas perusahaan diperoleh dari departemen perindustrian \& perdagangan, dan daftar di BEJ, ditambah.dengan yang belum mempublik tetapi sudah menerapkan \& 
mengembangkan sistem informasi untuk kegiatan operasionalnya. Responden yang dijadikan obyek penelitian ini adalah manajer pemasaran, -manajer personalia, manajer keuangan, dan manajer riset \& pengembangan. Alasan dipilihnya mereka sebagai obyek penelitian adalah karena mereka adalah pengguna sistem informasi yang dihasilkan oleh unit sistem informasi. Oleh karena itu mungkin persepsi mereka tentang kualitas pelayanan sistem informasi bisa berbeda-beda antara yang satu dengan yang lainnya. Peneliti membatasi respon pada jumlah minimal 30 responden untuk keperiuan statistik, tetapi tidak menutup kemungkinan untuk lebih dari jumlah tersebut. Data dikumpulkan melalui kuesioner yang disebarkan sebanyak 250 , dengan tingkat kembalian yang diharapkan $15-30 \%$ dari total responden. Kuesioner dikirimkan kepada masing-masing responden melalui sekretaris perusahaan dengan disertai surat permohonan pengisian kuesioner, kemudian peneliti membatasi waktu pengambilan jawaban responden kurang lebih dalam jangka waktu 1 minggu setelah pengisian. Dalam surat permohonan yang dikirimkan bersama kuesioner dijelaskan bahwa informasi yang diberikan responden dijamin kerahasiaannya. Hal tersebut dilakukan untuk menghindari keraguan responden dalam mengisi kuesioner, dan diberitahukan pula, apabila responden menghendaki ringkasan penelitian ini, peneliti akan mengirimkan ke alamat pemohon.

\section{Pelaksanaan Survei}

Kuesioner yang disebar adalah 250 eksemplar. Dari jumlah kuesioner yang dikirimkan, hanya 95 kuesioner yang dikembalikan, dan beberapa dinyatakan tidak bisa dianalisis karena data yang ada di dalamnya tidak lengkap. Sehingga jumlah kuesioner yang dapat digunakan untuk analisis adaiah sejumlah 43 eksemplar. Berikut adalah tabel yang menunjukkan jumlah kuesioner yang digunakan dalam penelitian ini:

Tabel 1

Hasil Pengembalian Kuesioner

\begin{tabular}{lrr}
\hline & Eksemplar & Prosentase \\
\hline Jumlah kuesioner yang dikirim & 250 & $100 \%$ \\
\hline Jumlah kuesioner yang kembali & 95 & $38 \%$ \\
\hline Jumlah kuesioner yang tidak lengkap & 52 & $20,8 \%$ \\
\hline Jumlah kuesioner yang memenuhi syarat untuk dianalisis & 43 & $17,2 \%$ \\
\hline
\end{tabular}

Adapun responden yang berpartisipasi dalam penelitian ini adalah responden yang menjalankan tugas fungsionalnya pada bidang keuangan $(22 \%)$, bidang pemasaran $(30,5 \%)$, personalia $(20 \%)$, dan sumber daya manusia $(27,5 \%)$.

\section{Pengukuran Variabel Variabel Dependen}

Variabel dependen adalah kualitas pelayanan yang diukur dengan menggunakan instrumen servqual (service quality) yang dikembangkan oleh 
Pitt, $d k k$ (dalam Sebastianus 1999). Instrumen ini terdiri atas dua bagian, yaitu expected dan perceived. Masing-masing bagian terdiri bagian terdiri atas 5 dimensi yaitu tangible (yaing diwakili oleh pertanyaan 1-4), reliability (diwakili oleh pertanyaan $5-9$ ), responsiveness (diwakili oleh pertahyaan $10-13$ ), assurance (diwakili oleh pertanyaan $14-17$ ), dan empathy (diwakili oleh pertanyaan 18-22). Skala yang digunakan adalah skala Likert dengan rentang nilai satu sampai dengan tujuh.

\section{Variabel Independen}

Variabel independen yaitu intensitas peran akuntansi manajemen dan ketidakpastian lingkungan. Untuk variabel intensitas peran akuntansi manajemen, item-item pertanyaan terdiri atas tiga bagian (8 pertanyaan), yaitu: sistem akuntansi manajemen, pengambilan keputusan, perencanaan dan pengendalian. Penelitian ini mengembangkan instrumen yang dikembangkan oleh (Harun, 1993; Hendarjatno, 1995; Yadiati, 1993; dalam Eka, 2000), yang sudah mengalami modifikasi susunan dan letak. Variabel tersebut diukur dengan menggunakan skala interval 7 poin (sangat tidak setuju - sangat setuju). Skor tersebut menunjukkan tingkat persetujuan responden tentang intensitas peran akuntansi manajemen. Untuk variabel ketidakpastian lingkungan, diukur dengan instrumen yang ditawarkan Gordon dan Narayan, 1994 (dalam Supardiyono, 1999) yang terdiri atas 5 pertanyaan, yang menyangkut ketidakpastian lingkungan yang dihadapi responden, antara lain bidang ekonomi, hukum politik, teknologi, pelanggan, dan lingkungan industri. Responden diminta menjawab pertanyaan dengan pilihan skala 1 sampai dengan 7. Jawaban responden untuk menentukan tingkat ketidakpastian lingkungan yang dihadapi perusahaan adalah rendah (ditunjukkan dengan skala rendah) atau tingkat ketidakpastian yang dihadapi perusahaan adalah tinggi (ditunjukkan dengan skala tinggi).

\section{Uji Reliabilitas dan Validitas}

Ketepatan pengujian suatu hipotesis tergantung pada kualitas data yang didapat dan dipakai dalam pengujian tersebut. Data penelitian tidak berguna apabila nstrumen yang digunakan untuk mengumpulkan data penelitian tidak memiliki eliabilitas dan validitas (Cooper dan Emory, 1995). ji Reliabilitas dimaksudkan untuk mengetahui sejauh mana hasil pengukuran tetap konsisten, apabila dilakukan pengukuran dua kali atau lebih terhadap gejala yang sama dengan menggunakan alat ukur yang sama. Peneiliti menggunakan uji reliabilitas dengan menghitung cronbach's alpha dari masing-masing instrumen dalam satu variabel. Instrumen yang dipakai dalam suatu variabel dikatakan andal (reliable) apabila memiliki cronbach's alpha lebih dari atau sama dengan 0,7 (Nunnaly dan Bernstein, 1994). Uji validitas dilakukan dengan analisis faktor, untuk memastikan bahwa masing-masing pertanyaan akan terklarifikasi pada variabel-variabel yang telah ditentukan (construct validity). Suatu variabel dikatakan valid apabila memiliki faktor loading sebesar lebih dari atau sama dengan 0,40 (Hair, dkk, 1995). 


\section{Metode Analisis Data}

Metode uji beda dua rata-rata dengan t-test pada tingkat signifikansi 5\%, digunakan untuk menguji hipotesis pertama. Perbedaan antara rata-rata hitung dua sampel dicari dengan menghitung rasio-t ( $t$-ratio). Rasio-t dihitung dengan mencari selisih antara rata-rata hitung kelompok sampel ke-1 dengan kelompok sampel ke-2 dibagi simpangan baku perbedaan rata-rata hitung kelompok sampel ke-1 dan ke-2. Apabila statistik hitung (angka t-outpuf) lebih besar dari statistik tabel (tabel t), maka Ho ditolak. Untuk menguji hipotesis kedua dan ketiga digunakan analisis regresi berganda. Multiple Regression Analysis digunakan untuk menguji kekuatan hubungan antara variabel dependen (kualitas pelayanan) dengan variabel independen (intensitas peran akuntansi manajemen dan ketidakpastian lingkungan). Analisis MRA pada dasarnya merupakan ekstensi dari metoda regresi dalam analisis bivariate yang umumnya digunakan untuk menguji pengaruh dua atau lebih variabel independen terhadap variabel dependen dengan skala pengukuran interval atau rasio dalam suatu persamaan linier. Untuk menguji hipotesis kedua dan ketiga, ditempuh dengan cara menghitung masing-masing dimensi harapan dan kenyataan (persepsian). Hasilnya kemudian diselisihkan untuk mendapatkan gap. Gap tersebut kemudian diregresi dengàn intensitas peran akuntansi manajemen dan ketidakpastian lingkungan. Secara statistik

$\mathrm{H} 2$ dan $\mathrm{H} 3$ dirumuskan sebagai berikut:

Ho; $\mathrm{b} 1=\mathrm{b} 2=0$

$\mathrm{Ha}$; b1 $\neq 0$, atau b2 $\neq 0$, atau b1, b2 $\neq 0$

Pengujian dengan regresi dilakukan dengan mengestimasi model berikut:

$\mathrm{Y}=\mathrm{b}+\mathrm{b} 1 \mathrm{X} 1+\mathrm{b} 2 \mathrm{X} 2 \ldots+\mathrm{e}$

Keterangan:

$\mathrm{Y}=$ kualitas pelayanan

b1 \& b2 = koefisien regresi

$\mathrm{X} 1=$ intensitas peran akuntansi manajemen

$\times 2=$ ketidakpastian lingkungan.

Bila koefisien (b1 dan b2) secara statistik signifikan (pada tingkat 5\%), maka Ho ditolak, yang berarti intensitas peran akuntansi manajemen dan ketidakpastian lingkungan mempunyai kaitan secara positif dengan kualitas pelayanan unit sistem informasi.

\section{ANALISIS DATA}

\section{Statistik Deskriptif}

Analisis didasarkan pada jawaban responden sebanyak 43 data, dan pada tabel 2 menunjukkan statistik deskriptif dari jawaban responden. Pada selisih antara harapan dan kenyataan terdapat rata-rata gap sebesar 12,8140 dengan deviasi standar sebesar 2,5935 , sedangkan rata-rata dari total jawaban responden pada intensitas peran akuntansi manajemen sebesar 37,4884 dengan 
Drajat Armono: Pengaruh Intensitas Peran Akuntansi Manajemen dan Ketidakpastian...

deviasi standar sebesar 8,4215 . Pada rata-rata jawaban dari total pada ketidakpastian lingkungan mempunyai nilai sebesar 26,7907 dengan deviasi standar sebesar 7,5042.

Tabel 2

Statistik deskriptif jawaban responden

\begin{tabular}{lcc|c} 
& Mean & Std. Deviation & $\mathrm{N}$ \\
\hline GAP $^{*}$ & 12,8140 & 2,5935 & 43 \\
Intensitas Peran Akuntansi Mnj. & $37,4884$. & 8,4215 & 43 \\
Ketidakpastian Lingktungan & 26,7907 & 7,5042 & 43 \\
\hline
\end{tabular}

\section{Pengujian Reliabilitas dan Validitas}

Dari hasil uji reliabilitas dapat disimpulkan bahwả kuesioner yang digunakan cukup reliabel, dilihat dari masing-masing nilai cronbach's alphanya yang lebih besar dari 0,7 (Nunnaly dan Bernstein, 1994). Dari hasil uji reliabilitas cronbach's alpha menunjukkan sebagai berikut:

Tabel 3

Hasil Uji Reliabilitas

\begin{tabular}{lc|c}
\hline & Jumlal item & $\begin{array}{c}\text { Cronbachs } \\
\text { alpha }\end{array}$ \\
\hline Kuesioner tentang Kualitas Pelayanan (Harapan) & 22 & 0,9357 \\
Kuesioner tentang Kualitas Pelayanan (Kenyataan) & 22 & 0,9268 \\
Kuesioner tentang Intensitas Peran Akuntansi Mañajemen & 8 & 0,8173 \\
Kuesioner tentang Ketidakpastian Lingkungan & 6 & 0,8486 \\
\hline
\end{tabular}

Kemudian kriteria mendasar yang berhubungan dengan validitas konstruk adalah validitas muka atau isi (Parasuraman, $d k k, 1984)$. Sebuah informasi dikatakan efektif apabila informasi tersebut dapat memenuhi kebutuhan pengguna untuk pengambilan keputusan. Berdasar uji validitas dengan menggunakan analisis faktor, menunjukkan hasil untuk masing-masing item dalam kualitas pelayanan, intensitas peran akuntansi manajemen, dan ketidakpastian lingkungan mempunyai nilai analisis faktor di atas 0,4 , yang berarti bahwa semua item pertanyaan pada kuesioner cukup valid untuk digunakan dalam penelitian ini. Hasil uji validitas item-item dalam kuesioner adalah sebagai berikut: 
Tabel 4

Hasil Uji Validitas masing-masing item pertanyaan

\begin{tabular}{|c|c|c|c|c|c|c|}
\hline No & $\begin{array}{c}\text { Item } \\
\text { IHARAPAN }\end{array}$ & $\begin{array}{c}\text { Item } \\
\text { KENYATAAN }\end{array}$ & $\begin{array}{c}\text { Ifem } \\
\text { IPAM }\end{array}$ & $\begin{array}{c}\text { Item } \\
\text { Ketidakpastian } \\
\text { Linģkunģan }\end{array}$ & $\begin{array}{c}\text { Syarat } \\
\text { Kevalidan }\end{array}$ & $\begin{array}{c}\text { Status } \\
\text { Kevalidan }\end{array}$ \\
\hline 1 & 0,606 & 0,558 & 0,638 & 0,754 & 0,4 & Valid \\
\hline 2 & 0.648 & 0.410 & 0,647 & 0,806 & 0,4 & Valid \\
\hline 3 & $\overline{0.586}$ & $0 . \overline{534}$ & 0,680 & 0.786 & 0.4 & Valid \\
\hline 4 & 0,507 & 0,654 & 0,679 & 0,658 & 0,4 & Valid \\
\hline 5 & 0,604 & 0,698 & 0,709 & 0,752 & 0,4 & Valid \\
\hline 6 & 0,672 & 0.755 & 0,749 & 0,770 & 0,4 & Valid \\
\hline 7 & 0,849 & 0,725 & 0,427 & - & 0,4 & Valid \\
\hline 8 & 0,824 & 0,683 & 0,784 & - & 0,4 & Valid \\
\hline 9 & 0,694 & 0.516 & - & - & 0,4 & Valid \\
\hline 10 & 0.720 & 0,819 & - & - & 0,4 & Valid \\
\hline 11 & 0,649 & 0.608 & - & - & 0,4 & Valid \\
\hline 12 & 0,762 & $\overline{0,564}$ & - & - & 0,4 & Valid \\
\hline 13 & 0,832 & 0,670 & - & $=$ & 0,4 & Valid \\
\hline 14 & 0,738 & 0.702 & - & $\cdot-$ & 0,4 & Valid \\
\hline 15 & 0,542 & 0,749 & - & - & 0,4 & Valid \\
\hline 16 & 0,700 & 0,768 & - & - & 0,4 & Valid \\
\hline 17 & 0,806 & $0,7 \mathrm{~s} 0$ & - & - & 0,4 & Valid \\
\hline 18 & 0,557 & 0,580 & - & - & 0,4 & Valid \\
\hline 19 & 0,749 & 0,736 & - & - & 0,4 & Valid \\
\hline 20 & 0,542 & $0, \sqrt{2} 22$ & - & - & 0,4 & Valid \\
\hline 21 & 0,683 & 0.487 & - & : & $\overline{0,4}$ & Valid \\
\hline 22 & 0,555 & 0,562 & - & - & 0.4 & Valid \\
\hline
\end{tabular}

\section{Uji Asumsi Klasik}

Secara teoritis perlu dipenuhinya asumsi klasik regresi yang meliputi asumsi normalitas, autokorelasi, multikolienaritas, dan heteroskedastisitas, supaya model penelitian menghasilkan nilai parameter dengan model penduga yang sahih.

\section{Normàlitas}

Peneliti memperoleh data sejumlah 43 responden, berarti hal tersebut sesuai dengari batas jumlah sampel yang dapat digunakan untuk keperluan statistik. Menurut Central Limit Theorema, jumlah minimal sampel untuk mencapai kurva normal adalah 30 (Mendenhall dan Beaver, 1992 dalam Wahyu; 2001). Jadi secara teoritis penelitian ini memenuhi asumsi normalitas. Juga berdasarkan pada lampiran, dengan menggunakan Kolmogorov-Smirnov tes 
Draja: Armono: Pengaruh Intensitas Peran Akuntansi Manajemen dan Ketidakpastian...

m

menghasilkan nilai yang tidak signifikan pada alpha $5 \%$, yaitu untuk GAP=0,555, intensitas peran akuntansi manajemen $=0,360$, dan ketidakpastian lingkungan $=0,260$, sehingga dapat dikatakan bahwa data yang digunakan dalam penelitian ini adalah normal.

\section{Autokorelasi}

Uji autokorelasi dapat dilakukan dengan melihat nilai Durbin-Watson. Uji autokorelasi yang didapat dari nilai DW sebesar 2,085. Adapun hasil pengujian disajikan sebagai berikut:

Tabel 5

Hasil perhitungan Durbin-Watson

\begin{tabular}{|c|c|c|c|c|c|}
\hline Model & $\mathrm{R}$ & R Square & $\begin{array}{l}\text { Adjusted R } \\
\text { Square }\end{array}$ & $\begin{array}{l}\text { Std. Error of } \\
\text { Estimate }\end{array}$ & Durbin-Watson \\
\hline $1=$ & 0.879 & 0,772 & 0.761 & 1,2686 & 2,085 \\
\hline
\end{tabular}

a. Predictors: (Constant), Ketidakpastian Lingk., IPAM

b. Dependent variable: GAP

Nilai Durbin-Watson sebesar 2;085 bisa kita bandingkan dengan menggunakan tabel dengan derajat kepercayaan $5 \%$ (Algifari, 2000), yaitu jumlah sampel 43 dan jumlah variabel independen 2, maka di tabel Durbin-Watson akan didapat nilai $\mathrm{dL}=1,391$ dan $\mathrm{dU}=1,600$. Oleh karena nilai $\mathrm{DW} 2,085$ lebih besar daripada batas atas (dU) 1,600, maka dapat disimpulkan tidak terdapat autokorelasi positif pada model regresi, karena menurut Imam Ghozali (2002) apabila nilai DW diatas nilai dU maka tidak terjadi autokorelasi.

\section{Multikolinearitas}

Uji ini dapat dilakukan dengan melihat hasil tolerance value atau variance inflation factor(VIF). Hasilnya menunjukkan bahwa perhitungan tolerance value adalah 1,000 yang berarti lebih besar dari 0,10 atau VIF adalah sebesar 1,000 yang berarti lebih kecil dari 10 pada setiap variabel independen yang diuji. Jadi data dalam penelitian ini sudah memenuhi asumsi tidak adanya multikolinearitas.

Berikut hasil uji tersebut:

Tabel 6

Hasil Perhitungan Kolinieritas

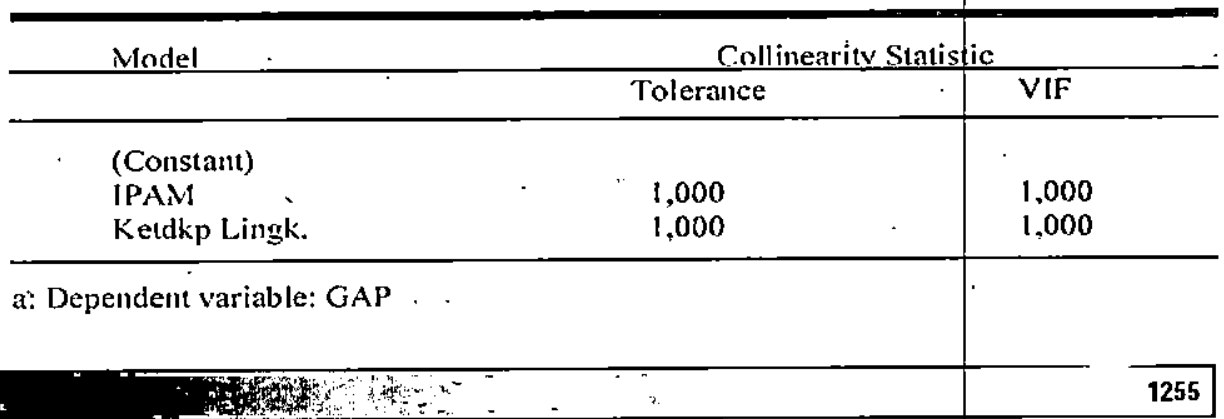


Uji ini juga dapat dilakukan dengan cara meregresikan antar kedua variabel independen (intensitas peran akuntansi manajemen dengan ketidakpastian lingkungan). Hasil yang didapat adalah pada tingkat signifikansi sebesar 0,980, sehingga dapat disimpulkan tidak adanya multikolinieritas antar variabel pada penelitian ini.

\section{Heteroskedastisitas}

Uji heteroskedastisitas dapat dilakukan dengan melihat sebaran titik-titik secara acak pada suatu grafik yang tidak membentuk pola tertentu yang jelas, baik di atas maupun di bawah angka 0 pada sumbu Y. Peneliti melakukan uji heteroskedastisitas dengan menggunakan Spearman's rho nonparametric correlation yang menghasilkan tingkat signifikansi pada variabel IPAM sebesar 0,416 dan pada variabel Ketidakpastian Lingkungan sebesar 0,738 , maka hal tersebut menunjukkan bahwa tidak terjadi heteroskedastisitas karena dengan tingkat alpha $5 \%(0,05)$, maka kedua variabel hasil uji tersebut tidak signifikan sehingga dapat disimpulkan tidak adanya heteroskedastisitas.

\section{Uji Interaksi}

Uji interaksi atau sering disebut dengan Moderated Regression Analysis (MRA) merupakan aplikasi khusus regresi berganda linier dan salah satu tujuannya adalah untuk menguji keterkaitan atau interaksi antar variabel-variabel independen, apakah diantara variabel-variabel itu layak sebagai variabel independen atau merupakan variabel pemoderasi yang mempengaruhi variabel dependen. Pada penelitian ini, peneliti menguji dan akan membuktikan bahwa kedua variabel independen yaitu intensitas peran akuntansi manajemen dan ketidakpastian lingkungan ataupun salah satu dari kedua variabel tersebut bukan merupakan variabel pemoderasi. Hasil uji ini dapat dilihat pada tabel berikut:

Tabel 7

Hasil Uji Interaksi

\begin{tabular}{|c|c|c|c|c|c|}
\hline \multirow[t]{2}{*}{ Model } & \multicolumn{2}{|c|}{$\begin{array}{l}\text { Unstandardized } \\
\text { Coelficients }\end{array}$} & \multirow{2}{*}{$\begin{array}{l}\text { Standardized } \\
\text { Coeflicients } \\
\text { Beta }\end{array}$} & \multirow[t]{2}{*}{$\mathbf{t}$} & \multirow[t]{2}{*}{ Sig } \\
\hline & B & Std. Error & & & \\
\hline$\downarrow$ (constant) & -4.743 & 3.917 & & -1.211 & .233 \\
\hline IPAM & .307 & .096 & .995 & 3.197 & .003 \\
\hline Ketdkp Lingk. & .383 & .138 & 1.107 & 2.778 & .008 \\
\hline Moderate & $-4.14 \mathrm{E}-03$ & .003 & -.616 & -1.234 & .225 \\
\hline
\end{tabular}

a: Dependent variable: GAP

Dari ketiga variabel independen yang dimasukkan dalam regresi, variabel intensitas peran akuntansi dan ketidakpastian lingkungan berpengaruh secara signifikan terhadap kualitas pelayanan unit sistem informasi dalam hal ini GAP yang digunakan. Variabel intensitas peran akuntansi manajemen signifikan pada tingkat signifikansi 0.003 dan variabel ketidakpastian lingkungan signifikan pada tingkat signifikanși 0.008. Variabel moderate yang merupakan interaksi antara intensitas peran akuntansi manajemen dan ketidakpastian lingkungan ternyata 
Drajat Armono: Pengaruh Intensitas Peran Akuntansi Manajemen dan Ketidakpastian...

0 a $a$ a $=$

tidak signifikan, yaitu pada tingkat signifikansi-0.225, sehingga dapat disimpulkan bahwa variabel ketidakpastiari lingkungan bukanlah merupakan variabel pemoderasi pada penelitian ini. Menurut Imam Ghozali (2002) apabila variabel moderate tidak signifikan, maka dapat disimpulkan bahwa variabel tersebut bukan merupakan variabel pemoderasi.

\section{Pengujian Hipotesis}

\section{Pengujian Hipotesis 1}

Untuk menguji hipotesis pertama digunakan alat uji paired samples. Dari hasil perhitungan, diperoleh nilai t sebesar 32,479 dengan probabilitas (sig. 2 tailed) adalah sebesar 0,000, (dengan $\mathrm{df}=42$ ) maka dapat disimpulkan bahwa Ho tidak didukung. Hasil lengkap dapat dilihat sebagai berikut:

Tabel 8 Hasil perhitungan t test

\begin{tabular}{|c|c|c|c|c|c|c|c|c|}
\hline . & Meaiı & $\begin{array}{c}\text { Std } \\
\text { Deviation }\end{array}$ & $\begin{array}{c}\text { Std } \\
\text { Error } \\
\text { Mean }\end{array}$ & $\begin{array}{r}95 \% \mathrm{C} \\
\text { Inte } \\
\text { Difre }\end{array}$ & $\begin{array}{l}\text { nfidence } \\
\text { val of } \\
\text { ences } \\
\end{array}$ & $t$ &. & $\begin{array}{r}\text { Sig } \\
\text { (2 tailed) }\end{array}$ \\
\hline & & & & Lower & Upper & & & \\
\hline $\begin{array}{l}\text { Harapan- } \\
\text { Kenyataan }\end{array}$ & 12.8605 & 2.5965 & .3960 & $\begin{array}{c}12.0614 \\
.\end{array}$ & 13.6596 & 32.479 & +2 & .000 \\
\hline
\end{tabular}

Dengan demikian berdasar bukti empiris yang diperolah di lapangan, $\mathrm{Ha}$ yang berbunyi "Ada perbedaan antara kualitas layanan harapan (ekspektasian) dengan kualitas layanan kenyataan (persepsian) yang diberikan oleh unit sistem informasi kepada manajer-manajer di luar unit sistem informasi" didukung, artinya berdasar bukti-bukti yang diperoleh terdapat perbedaan yang șignifikan antara kualitas layanan harapan (ekspektasian) dengan kualitas layanan kenyataan (persepsian) yang diberikan oleh unit sistem informasi kepada para manajer di luar unit sistem informasi. Hal ini senada dengan penelitian yang dilakukan oleh Parasuraman, dkk,1988; Boulding dan Stealing, 1993; Pitt, dkk, 1995; Sebastianus, 1999. Berdasar kenyataan yang ada, kualitas pelayanan yang diberikan oleh unit sistem informasi masih kurang di berbagai perusahaan. $\mathrm{Hal}$ tersebut dapat dilihat dari nilai harapan yang lebih besar dibanding dengan nilai kenyataan dari kualitas pelayànan unit sistem informasi tersebut.

\section{Pengujian Hipotesis 2 dan 3}

Hipotesis kedua yang menyatakan bahwa "Intensitas peran akuntansi manajemen berpengaruh secara positif terhadap kualitas pelayanan yang diberikan oleh unit sistem informasi", diuji dengan persamaan regresi. Hipotesis ketiga yang menyatakan bahwa "Ketidakpastian lingkungan berpengaruh secara positif terhadap kualitas pelayanan yang diberikan oleh unit sistem informasi", diuji secara berșama-sama dengan persamaan regresi. Untuk menguji hipotesis. kedua dan ketiga digunakan analisis regresi berganda dengan persamaan matematisnya sebagai berikut: 


$$
Y=b+b 1 X 1+b 2 X 2+e
$$

Adapun hasil regresi untuk masing-masing variabel independen terhadap variabel dependennya tampak pada tabel berikut ini:

Tabel 9

Hasil Perhitungan Regresi Berganda

\begin{tabular}{|c|c|c|c|c|c|}
\hline \multirow[t]{2}{*}{ Model } & \multicolumn{2}{|c|}{$\begin{array}{l}\text { Unstandardized } \\
\text { Coerficients }\end{array}$} & \multirow{2}{*}{$\begin{array}{l}\begin{array}{l}\text { Standardized } \\
\text { Coellicients }\end{array} \\
\text { Beta }\end{array}$} & \multirow[t]{2}{*}{$t$} & \multirow[t]{2}{*}{$\mathrm{Sig}$} \\
\hline & B & Sid. Error & & & \\
\hline $\begin{array}{l}1 \text { (constant) } \\
\text { IPAM } \\
\text { Ketdkp Lingk. }\end{array}$ & $\begin{array}{l}-.151 \\
.193 \\
.213\end{array}$ & $\begin{array}{l}1.136 \\
.023 \\
.026\end{array}$ & $\begin{array}{l}.628 \\
.617\end{array}$ & $\begin{array}{l}-.133 \\
8.321 \\
8.175\end{array}$ & $\begin{array}{l}.895 \\
.000 \\
.000\end{array}$ \\
\hline $\begin{array}{l}\mathrm{F} \\
\mathrm{R} \\
\mathrm{R} \text { Square } \\
\text { Adjusted R Squa }\end{array}$ & $\begin{array}{l}=67.766 \\
=.879 \\
=.772 \\
e=.761\end{array}$ & $\therefore \operatorname{Sig}=$ & 00 & & - \\
\hline
\end{tabular}

a: Dependent variable: GAP

Pengujian dengan menggunakan regresi berganda ini tampak pada tabel di atas yang menunjukkan bahwa hipotesis kedua didukung secara signifikan ( $P$ val $=0,000$ lebih kecil dari $\alpha=0,05$ atau 5\%), sedangkan hipotesis ketiga juga didukung secara signifikan ( $P$ val $=0,000$ lebih kecil dari $\alpha=0,05$ atau $5 \%$ ). Penelitian ini menunjukkan bahwa intensitas peran akuntansi manajemen berpengaruh terhadap kualitas pelayanan sistem informasi, begitu pula ketidakpastian lingkungan juga berpengaruh terhadap kualitas pelayanan sistem informasi. Hal ini berlawanan dengan (Wahyu, 2001) yang menyatakan ketidakpastian lingkungan tidak berpengaruh secara signifikan pada tingkat alpha $5 \%$. Tampilan output spss juga menunjukkan besarnya $R=0,879$ atau $87,9 \%$ yang menunjukkan bahwa hubungan atau korelasi antara kualitas pelayanan (variabel dependen) dengan variabel independennya (intensitas peran akuntansi manajemen \& ketidakpastian lingkungan) adalah kuat. Adjusted R square sebesar 0,761 atau $76,1 \%$ menunjukkan bahwa variasi dalam kualitas pelayanan dijelaskan oleh peran intensitas akuntansi manajemen dan ketidakpastian lingkungan sebesar $76,1 \%$, sedangkan $23,9 \%$ dijelaskan oleh sebab-sebab atau variabel lain diluar model. Hasil pengujian Anova atau uji $F$ adalah 67,766 dengan prob-value $=0,000$, nilai signifikansi $F$ lebih rendah dibanding dengan alpha yang digunakan yaitu sebesar $5 \%$, yang berarti variabel independen (intensitas peran akuntansi manajemen dan ketidakpastian lingkungan) secara bersama-sama berpengaruh terhadap variabel dependen (kualitas pelayanan). 


\section{Simpulan}

Dari pengujian tersebut diperoleh simpulan sebagai berikut:

Hasil pengujian regresi untuk hipotesis pertama yang menunjukkan bahwa ada perbedaan kualitas pelayanan signifikan pada 0,000 , sehingga dapat disimpulkan bahwa terdapat perbedaan antara kualitas pelayanan harapan (ekspektasian) dengan kualitas pelayanan kenyataan (persepsian). Hal ini senada dengan penelitian yang dilakukan oleh Parasuraman, dkk, 1988; Boulding dan Stealing, 1993; Pitt, dkk, 1995; Sebastianus, 1999. Berdasar kenyataan yang ada, kualitas pelayanan yang diberikan oleh unit sistem informasi masih kurang di berbagai perusahaan. Hal tersebut dapat dilihat dari nilai harapan yang lebih besar dibanding dengan nilai kenyataan dari pelayanan unit sistem informasi.

Hipotesis kedua didukung (Pval $=0,000$ pada $\alpha=0,05$ atau $5 \%$ ). Hasil pengujianregresi yang tampak pada tabel 4.8 , di bab 4 menunjukkan dan dapat disimpulkan bahwa ada pengaruh secara positif yang signifikan dari intensitas peran akuntansi manajemen terhadap kualitas pelayanan yang diberikan oleh unit sistem informasi kepada unit lain di luar unit sistem informasi. Hal tersebut memberikan bukti baru bahwa temyata intensitas peran akuntansi manajemen mempunyai pengaruh yang positif terhadap kualitas pelayanan unit sistem informasi dalam perusahaan.

Hipotesis ketiga didukung ( $P$ val $=0,000$ pada $\alpha=0,05$ atau $5 \%$ ). Hasil pengujian regresi yang tampak pada tabel menunjukkan bahwa ketidakpastian lingkungan berpengaruh secara positif terhadap kualitas pelayanan yang diberikan oleh unit sistem informasi kepada unit lain di luar unit sistem informasi. Hal ini berlawanan dengan (Wahyu, 2001) yang menyatakan ketidakpastian lingkungan tidak berpengaruh secara signifikan pada tingkat|alpha $5 \%$.

\section{Kéterbatasan}

Beberapa keterbatasan yang ada antara lain:

1. Penelitian ini tidak menunjukkan penyebab perbedaan persepsi yang terjadi, sehingga dikhawatirkan responden akan mempunyai persepsi yang berbeda-beda, sehingga akan mempengaruhi hasil akhir dari penelitian ini.

2. Perbedaan hasil dimungkinkan karena pemilihan populasi yang berbeda.

3. Perbedaan ukuran sampel dapat membuat hasil yang berbeda.

\section{Implikasi}

Hasil penelitian ini menunjukkan bahwa intensitas peran akuntansi manajemen dan ketidakpastian lingkungan memerlukan analisis lebih lanjut untuk bisa dijadikan faktor penyebab perbedaan persepsi kualitas pelayanan yang diberikan oleh unit sistem informasi. Hasil penelitian ịi akan mempunyai implikasi pada penelitian akuntansi manajemen dimasa yang akan datang. Selain itu bagi unit manufaktur, penelitian ini bermanfaat dan dapat dijadikan masukan untuk dapat memperhatikan faktor apa saja yang akan mempengaruhi 
kualitas dari unit sistem informasi dalam suatu perusahaan. Penelitian mendatang juga dapat menambahkan faktor-faktor lain yang dapat mempengaruhi perbedaan persepsi antar manajer tèrhadap kualitas pelayanan unit sistem informasi.

\section{DAFTAR PUSTAKA}

Algifari. Analisis Regresi, Teori, Kasus dan Solusi. Edisi ke-2, BPFE, Yogyakarta, 2000.

Anthony, Robert N, dan Vijay Govindarajan. Management Control Systems. Edisi ke-10. Boston, McGraw-Hill. 2001.

Boulding, dan R. Stealing. A Dynamic Process Model of Service Quality Assesment. The Service Quality Handbook. Edited by Eberhard E.S. dan F: C. William. Amacom, New York. 1993.

Burn, T dan G. M. Staker. The Management of Innovation. London: Tavistock, 1961.

Chenhall, R. H dan D. Morris. The Impact of Structure, Environment, and Interdependence on the Perceived Usefulness of Management Accounting Systems. Accounting Review. 16-35, 1986.

Cooper, D. R dan Emory, C.W. Business Research Methods. Irwin, Home Wood, Illinois, 5th ED, 1995.

Dabholkar, P. A., Thorpe, D. L., dan Rentz, J. O. A Measure of Service Quality for Retail Store: Scale Development and Validation. Journal of Academy of Marketing Science. Vol.24, No. 1: 3-16, 1996.

Ghozali, Imam. Aplikasi Analisis Multivariate dengan Program SPSS. Edisi 2, BP Undip, Semarang, 2002.

Gordon, G. A dan Narayanan, V. K. Management Accounting System, Perceived Environment Uncertainty and Organizational Structure: An Empirical Analysis Investigation. Accounting Organization and Society, Vol. 9 No. 1: 33-47, 1984.

Gujarati, Damadar N. Basic Econometrics. Edisi 3, McGraw-Hill, International Edition, Economic Series, 1995.

Hair, Z. F., R.E. Anderson, R. L. Thatan, dan B. J. Grabolosky. Multivariate Data Analysis. Edisi ke-4, Tulsa, OK: Petroleum Publishing \& Co, 1995. 
Drajat Armono: Pengaruh Intensitas Peran Akuntansi Manajemen dan Ketidakpastian...

Indriantoro, Nur dan Bambang Supomo. Metodologi Penelitian dan Bisnis untuk Akuntansi dan Manajemen. Edisi pertama, BPFE, Yogyakarta. 1999.

Khandwalla, P. The Effect of Different Types of Compefition on the Use Management Controls. Journal of Accounting Research. 10:275-285, 1972.

Kottler, John P, dan James L. Heskett. Corporate Culture and Performance. New York: The Free Press. 1992.

Mia, Lockman dan Robert $\mathrm{H}$ Chenhall. The Usefulness of Management Accounting System, Functional Differentiation and Managerial Effectiveness. Accounting Organizations and Society, Vol. 19, No. 1: $1-13,1994$.

Nazaruddin, I. Pengaruh Desentralisasi dan Karakteristik Informasi Sistem Akuntansi Terhadap Kinerja Manajerial. Jurnal Akuntansi Indonesia, Vol:'1, No. 2, Juli:141-162, 1998.

Nunnaly, J. C. Psycometric Theory. New York: Mc Graw-Hill, 1967.

Nunnaly, Jun, C dan Ira H Bernstein. Psycometric Theory. Third Edition, Mc Graw-Hill, Inc, New York, 1994.

Outley, D. T. The Contigency Theory of Management Accounting: Achievement and Prognosis. Accounting, Organizations and Society, pp: 413-428, 1980.

Parasuraman, A, Zithmal. V. A., dan L. L. Berry. Servqual, A Multipie ltem Scale for Measuring Consumer Perceptions of Service Quality. Joumal of Retailing. Vol. 64, Iss 1, Spring: 12-40. 1988.

Pitt, L. F., R.T. Watson, dan C. B. Kavan. Service Quality: A Measure of Information Systems Effectiveness. MIS Quarterly. Pp 173-185, June 1995.

Priastana Putra, Eka. Budaya Organisasi dan Intensitas Peran Akuntansi Manajemen: Penelitian Empiris pada Perusahaan-Perusahaan di Indonesia.Tesis, Program S2 UGM. 2000.

Rasyid, Eddy R. Saling Peran (Interplay) antara Akuntansi dan Budaya Perusahaan: Penelitian Empiris dengan Metode Interpretif Etnografis. Jurnal Riset Akuntansi Indonesia 1 (1) Januari 1998.

Reiner, R.K. Jr dan H. J. Watson. The Key to Executive Information System Success. Journal of Management Information System. Vol. 12, No. 2 , pp. 83-98, Fall1995. 
Sebastianus. Pengaruh Karakteristik Perusahaan Terhadap Keefektifan Sistem Informasi Ditinjau dari Dimensi.Kualitas Pelayanan. Tesis Program S2 UGM, 1999.

Singgih Santoso. SPSS: Mengolah Data Statistik Secara Profesional. Gramedia, Jakarta, 2001.

Sjoblom, Leif M. Financial Information and Quality Management - Is There a Role for Accountant?. Accounting Horizons 12 (4), pp. 363-373. 1998.

Sudibyo, Bambang. Rekayasa Akuntansi dan Permasalahannya di Indonesia. Makalah. Pada HUT IAI ke-29 di Jakarta, tanggal 22 Desember 1986.

Suhaily, L. The Usefulness of The Servqual Technique for Measuring Quality in The Hotel Industry. Atma Nan Jaya, April: 39-47, 1999.

Sumodiningrat, Gunawan. Ekonomika Pengantar. Cetaḳan Ketiga BPFE, Yogyakarta, 1996.

Wahyu Sapto Rini. Pengaruh Struktur Organisasi dan Ketidakpastian Lingkungan terhadap Efektifitas Sistem Informasi. Tesis, Program S2, UGM. 2001.

Wilkinson, Zoseph. Accounting Information System. Fourth Edition, John Willey and Son, Inc, 2000.

Y.P. Supardiyono. Pengaruh Ketidakpastian Lingkungan dan Struktur Organisasional terhadap Efektivitas Sistem Akuntansi Manajemen dalam Peningkatan Kinerja Manajerial. Tesis, Program S2, UGM. 1999. 